\title{
Genetic Relationships between Cultivated and Wild Olive Trees (Olea europaea L. var. europaea and var. sylvestris) Based on Nuclear and Chloroplast SSR Markers
}

\author{
Hédia Hannachi ${ }^{*}$, Catherine Breton ${ }^{2}$, Monji Msallem ${ }^{3}$, Salem Ben El Hadj ${ }^{4}$, Mohamed El Gazzah ${ }^{1}$ \\ André Bervillé ${ }^{2}$ \\ ${ }^{1}$ Faculté des Sciences de Tunis, Département de Biologie, Campus Universitaire, Tunis, Tunisie; ${ }^{2}$ INRA, UMR1097, Bât. 33, 2 place \\ Viala, F-34060 Montpellier cedex 1, France; ${ }^{3}$ Institut de l'Olivier, Tunis, Tunisia; ${ }^{4}$ Institut National Agronomique de Tunisie, Tunis, \\ Mahrajène, Tunisia. \\ Email: hannachi_hedia@yahoo.fr
}

Received October $26^{\text {th }}, 2010$; revised November $29^{\text {th }}, 2010$; accepted November $30^{\text {th }}, 2010$.

\begin{abstract}
The olive is widely cropped in Tunisia where also oleaster trees thrive all around orchards and in natural sites. Little is known on the genetic relationships between the olive crop and oleaster trees in Tunisia. Fifty-two oleaster trees and fifteen cultivars were sampled from Tunisia. SSR genotyping was performed in polyacrylamide gels after fluorescent labeling. We used seven nuclear and two chloroplast SSR markers. AFC analyses showed close genetic relationships between cultivated and oleaster trees. Genetic relationships were also displayed in a dendrogram based on Unweighted Pair Group Method (UPGMA). Five clusters were defined mixing cultivar and oleaster trees suggesting close relationship between some cultivar and some oleaster trees. One oleaster is single in a cluster. The chlorotype SSR markers show probably three olive origins. Some cultivars have the CE chlorotype originates from the East of the Mediterranean basin, the CCK haplotype originates from Maghreb and the COM chlorotype originates from West Mediterranean. The cultivars were 1) introduced from the East; 2) selected in the West; 3) or selected in the North Africa region. The Tunisian oleaster trees carry eastern and western Mediterranean chlorotype CCK, COM and CE.
\end{abstract}

Keywords: Cultivars, Oleaster, Genetic Relationship, SSR Markers, Haplotype, Origin

\section{Introduction}

Two olive (Olea europaea subsp. europaea var. europaea) varieties are distinguished by botanists in the Mediterranean basin namely var. europaea which is the cultivated form and var. sylvestris, the wild olive tree or oleaster.

The olive is one of both of the oldest tree crops with the fig tree and it is cultivated for oil and table olives. The olive is the most important oil producing crop in the Mediterranean region. Olive oil has traditionally been used for pharmaceutical, industrial and consumer purposes. Tunisia is formerly a major producer of olive oil in North Africa. In Tunisia, about 60 million olive trees are cultivated in third of cultivated areas, most of them represented by two prevalent oil cultivars 'Chétoui' and 'Chemlali'. The rest is represented by several minor cul- tivars [1].

Little is known about the Tunisia oleaster trees and about their genetic relationships with cultivars. Genetic erosion and loss of biodiversity do not seem to be major issues for olive germplasms due to absence of turnover of new genotypes that do not occur as fast as in other woody crops. Moreover, old olive trees survive for a long time once abandoned [2,3].

Morphological traits in the olive do not enable differentiation between oleasters and cultivars. Although, several morphological descriptors show partial differentiation of them [4,5].

Recently, molecular markers have been developed in the olive [2,6-11] that enable cultivar differentiation and identification due to their high intra species variability.

The use of nuclear microsatellite markers for genetic analysis is well established in the olive [7,12-14]. The 
principle has been extended to the chloroplast $[15,16]$ and mitochondrial genomes $[3,17,18]$. The utility of molecular tools for evolutionary studies arises from the insensitivity of the genetic markers to environmental factors. Several markers based on DNA amplification technology have been used to look for genetic relationships between the cultivated olive (cultivars) and the oleaster trees as to structure its genetic diversity $[3,8,15,16]$, including DNA from nucleus, chloroplast (cpDNA) and mitochondria (mtDNA). Simple Sequence Repeats (SSRs) lead to multiallelic fragments and are easily amenable to Polymerase Chain Reaction (PCR) based analysis. Microsatellite markers explore various independent portions of the olive genome and they have been identified in plants' nuclear and mitochondrial genomes $[3,15,19]$ as well as in the chloroplast genome where they are mononucleotide [20]. With SSRs, Restriction Fragment Length Polymorphisms (RFLPs) are complementarily used to define chloroplast and mitochondrial RFLP data, using multiple pair wise combinations of probe and restriction enzyme to recognize distinct genetic patterns, called chlorotypes or mitotypes. Since the organelles are usually passed to offspring from the female parents, cytoplasm markers (mitochondria and chloroplast) trace maternal lineage only [21].

Many studies have shown the diversity of cultivars using morphological descriptors [1,22], but little attention has been given to the Tunisian oleasters $[4,5]$. In Tunisia a few studies have been made on cultivars using SSRs markers [23].

In the present study, an analysis of polymorphisms within and among the two olive taxa (cultivar and oleaster trees) was undertaken using nuclear and cytoplasm SSR markers. This will enable the determination of genetic groups or clusters to establish breeding programs that encompasses the genetic diversity of this species.

\section{Materials and Methods}

A total of 15 autochthonous Tunisian cultivars and 52 oleasters were sampled in the north of Tunisia (Table 1), all are presently cropped in wide area. They were subject to genotyping for chlorotypes previously described and developed. We used two markers ccmp5 and ccmp7 retained by authors $[8,21,22]$ and seven nuclear microsatellite markers, three ssrOeUA-DCA04, 05, 09 [11]; one ssrOe-GAPU 101 [25] and three ssrOe-UD012, 017, 024 [9], chosen as used by Breton et al. [14], (Table 2).

\subsection{DNA Amplifications}

Total DNA preparation was performed using the method described by Besnard et al. [21]. PCR reaction was performed in $12.5 \mu \mathrm{l}$ final volume, containing $40 \mathrm{ng}$ ge- nomic DNA, $0.75 \mathrm{mM} \mathrm{MgCl} 2,2.5 \mathrm{mM}$ dNTP, $1.25 \mathrm{U}$ Taq polymerase and $0.19 \mathrm{mM}$ M13-Fam. PCR amplifycation was conducted in a thermal cycler Gradient 96 Robocycler (Stratagene, Germany). The amplification program was $94^{\circ} \mathrm{CC}$ for $1 \mathrm{~min}, 52^{\circ} \mathrm{C}$ for $1 \mathrm{~min}, 72^{\circ} \mathrm{C}$ for $1 \mathrm{~min}$, followed by 35 cycles at $94^{\circ} \mathrm{C}$ for $30 \mathrm{~s}$, at $50^{\circ} \mathrm{C}$ for $45 \mathrm{~s}$ and at $72^{\circ} \mathrm{C}$ for $1 \mathrm{~min}$, with a final elongation cycle at $72^{\circ} \mathrm{C}$ for $4 \mathrm{~min}$.

Amplification products and ladders were labeled using the tailing method with the Fam fluorochrome. They were separated into $8 \%$ polyacrylamide gels enabling reading with a Hitachi scanner system associated with the FMBIO2 software [26].

The method used for chlorotype DNA-RFLP analysis was described by Besnard et al. [21] and Breton [13]. Two restrictions enzyme/probe combinations (HindIII/ atp6 and XbaI/atp6) were used to identify the chlorotype $\mathrm{CE}, \mathrm{COM}$ and CCK previously determined by Besnard et al. [21].

\subsection{Statistical Analysis}

Factorial Correspondence Analysis (FCA) was performed using GENETIX. Dendrogram was constructed with Unweighted Pair Group Method (UPGMA) algorithm based on Nei' genetic distances [27] and a neighbourjoining tree was constructed with the nuclear SSR data set using PHYLIP Version 3.5c [28].

\section{Results}

\subsection{Factorial Correspondence Analysis}

The plot of FCA coordinates for the first and the second axes, which explain $8.69 \%$ and $6.23 \%$ of variance, respectively and showed continuity in the distribution of oleaster and cultivar trees. However, most of cultivars clustered in the right of the cloud. Thus, we considered two clusters of genotypes (Figure 1). The cultivars cluster grouped three oleaster trees. In contrast, most oleaster trees clustered on the left with the cultivar C1 (Sayali).

\subsection{Clustering}

Olive cultivar and oleaster trees were clustered with the UPGMA method based on the Nei's similarity coefficient using SSR data (Figure 2). The clustering analysis showed five groups and one single oleaster (O11). Three clusters (CL1, CL2 and CL3) contain cultivars and oleaster trees and two other clusters (CL4 and CL5) contain only oleaster trees.

Cluster_1 (CL1) aggregated 11 out of 15 cultivars (C1 Sayali, C6 Marsaline, C10 Meski, C30 Rajou, C29 Limi, C26 Tounsi, C14 Gerboui, C20 Besbessi, C28 Zarras, C13 Neb Jmel and C22 Chaïbi) and 12 oleasters from several locations; six of them sampled from natural eco- 
(Olea europaea L. var. europaea and var. sylvestris) Based on Nuclear and Chloroplast SSR Markers

system $(\mathrm{O} 6, \mathrm{O} 8, \mathrm{O} 9, \mathrm{O} 13, \mathrm{O} 22, \mathrm{O} 26)$ and six from agroecosystem (O3, O32, O34, O35, O40 and O42). Some cultivars were close to oleasters from natural ecosystem. The cultivars C1 'Sayali', C13 'Neb Jmel', C14 'Gerboui', C22 'Chaïbi', C28 'Zarras' and C29 'Limi', were close to oleasters from natural ecosystem O6, O22, O8, O13, 026 and $\mathrm{O} 9$, respectively. Whereas, others cultivars were related to oleasters from agro-ecosystem: the cultivars C6 'Marsaline', C10 'Meski', C20 'Besbessi', C26
'Tounsi', C30 'Rajou' related to oleasters O3, O32, O40, O34 and O42, respectively.

Cluster_2 (CL2) aggregated nine oleasters (O61, O57, O1, O23, O19, O20, O53, O30, and O21) and two cultivars (C8 Chemlali and C27 Roumi). Three oleasters (O61, O19, and O20) were from natural ecosystem and six from agro-ecosystem. The cultivars C8 'Chemlali' and C27 'Roumi' were close to two oleasters from agroecosystem $\mathrm{O} 1$ and $\mathrm{O} 21$, respectively.

Table 1. Origins of cultivated (cultivars) and wild (oleasters) olive trees used in the present study.

\begin{tabular}{|c|c|c|c|c|}
\hline Code & Cultivar/oleaster & Location & Ecosystem & Governorate \\
\hline $\mathrm{C} 1$ & Sayali & Slouguia & Agro-ecosystem & Béja \\
\hline $\mathrm{C} 2$ & Chétoui & Slouguia & Agro-ecosystem & Béja \\
\hline C6 & Marsaline & Slouguia & Agro-ecosystem & Béja \\
\hline $\mathrm{C} 8$ & Chemlali & Slouguia & Agro-ecosystem & Béja \\
\hline $\mathrm{C} 10$ & Meski & Slouguia & Agro-ecosystem & Béja \\
\hline $\mathrm{C} 13$ & Neb jmel & Testour & Agro-ecosystem & Béja \\
\hline $\mathrm{C} 14$ & Gerboui & Slouguia & Agro-ecosystem & Béja \\
\hline $\mathrm{C} 20$ & Besbessi & Testour & Agro-ecosystem & Béja \\
\hline $\mathrm{C} 22$ & Chaïbi & Téboursouk & Agro-ecosystem & Béja \\
\hline $\mathrm{C} 26$ & Tounsi & Téboursouk & Agro-ecosystem & Béja \\
\hline $\mathrm{C} 27$ & Roumi & Téboursouk & Agro-ecosystem & Béja \\
\hline $\mathrm{C} 28$ & Zarras & Téboursouk & Agro-ecosystem & Béja \\
\hline $\mathrm{C} 29$ & Limi & Téboursouk & Agro-ecosystem & Béja \\
\hline $\mathrm{C} 30$ & Rajou & Ras jbel & Agro-ecosystem & Bizerte \\
\hline $\mathrm{C} 31$ & $\mathrm{Nib}$ & Ras jbel & Agro-ecosystem & Bizerte \\
\hline $\mathrm{O} 1$ & Oleaster & Slouguia & Agro-ecosystem & Béja \\
\hline $\mathrm{O} 3$ & Oleaster & Testour & Agro-ecosystem & Béja \\
\hline $\mathrm{O} 4$ & Oleaster & Testour & Agro-ecosystem & Béja \\
\hline O5 & Oleaster & Téboursouk & Agro-ecosystem & Béja \\
\hline O6 & Oleaster & Téboursouk & Natural ecosystem & Béja \\
\hline $\mathrm{O} 7$ & Oleaster & Ichkeul & Natural ecosystem & Bizerte \\
\hline $\mathrm{O} 8$ & Oleaster & Ichkeul & Natural ecosystem & Bizerte \\
\hline O9 & Oleaster & Ichkeul & Natural ecosystem & Bizerte \\
\hline $\mathrm{O} 10$ & Oleaster & Ichkeul & Natural ecosystem & Bizerte \\
\hline $\mathrm{O} 11$ & Oleaster & Ichkeul & Natural ecosystem & Bizerte \\
\hline $\mathrm{O} 12$ & Oleaster & Ichkeul & Natural ecosystem & Bizerte \\
\hline $\mathrm{O} 13$ & Oleaster & Ichkeul & Natural ecosystem & Bizerte \\
\hline $\mathrm{O} 15$ & Oleaster & Ras Jbel & Agro-ecosystem & Bizerte \\
\hline $\mathrm{O} 16$ & Oleaster & Ras Jbel & Agro-ecosystem & Bizerte \\
\hline $\mathrm{O} 17$ & Oleaster & Tunis & Natural ecosystem & Tunis \\
\hline $\mathrm{O} 18$ & Oleaster & Tunis & Natural ecosystem & Tunis \\
\hline $\mathrm{O} 19$ & Oleaster & Tunis & Natural ecosystem & Tunis \\
\hline $\mathrm{O} 20$ & Oleaster & Tunis & Natural ecosystem & Tunis \\
\hline $\mathrm{O} 21$ & Oleaster & Messaoudi & Agro-ecosystem & El Kef \\
\hline $\mathrm{O} 22$ & Oleaster & Midian & Natural ecosystem & El Kef \\
\hline $\mathrm{O} 23$ & Oleaster & Bahra & Agro-ecosystem & El Kef \\
\hline
\end{tabular}


Continued Table 1

\begin{tabular}{|c|c|c|c|c|}
\hline Code & Cultivar/oleaster & Location & Ecosystem & Governorate \\
\hline $\mathrm{O} 25$ & Oleaster & Ettouiref & Natural ecosystem & El Kef \\
\hline $\mathrm{O} 26$ & Oleaster & Ettouiref & Natural ecosystem & El Kef \\
\hline $\mathrm{O} 27$ & Oleaster & Jendouba & Natural ecosystem & Jendouba \\
\hline $\mathrm{O} 28$ & Oleaster & Fernana & Agro-ecosystem & Jendouba \\
\hline $\mathrm{O} 29$ & Oleaster & Jendouba & Natural ecosystem & Jendouba \\
\hline $\mathrm{O} 30$ & Oleaster & Tbaba & Agro-ecosystem & Jendouba \\
\hline $\mathrm{O} 31$ & Oleaster & Zouaraa & Agro-ecosystem & Béja \\
\hline $\mathrm{O} 32$ & Oleaster & Zouaraa & Agro-ecosystem & Béja \\
\hline $\mathrm{O} 33$ & Oleaster & Tamra & Agro-ecosystem & Béja \\
\hline $\mathrm{O} 34$ & Oleaster & Sejnan & Agro-ecosystem & Bizerte \\
\hline $\mathrm{O} 35$ & Oleaster & Sejnan & Agro-ecosystem & Bizerte \\
\hline $\mathrm{O} 37$ & Oleaster & Aïn Ghlal & Agro-ecosystem & Bizerte \\
\hline $\mathrm{O} 38$ & Oleaster & Jbel Elwesr & Natural ecosystem & Zaghouan \\
\hline O39 & Oleaster & Zaghouan & Agro-ecosystem & Zaghouan \\
\hline $\mathrm{O} 40$ & Oleaster & Zriba & Agro-ecosystem & Zaghouan \\
\hline $\mathrm{O} 42$ & Oleaster & Jradou & Agro-ecosystem & Zaghouan \\
\hline $\mathrm{O} 43$ & Oleaster & Jradou & Agro-ecosystem & Zaghouan \\
\hline $\mathrm{O} 44$ & Oleaster & Oued Kenz & Natural ecosystem & Zaghouan \\
\hline $\mathrm{O} 45$ & Oleaster & Batria & Agro-ecosystem & Zaghouan \\
\hline O46 & Oleaster & Saouaf & Agro-ecosystem & Zaghouan \\
\hline $\mathrm{O} 47$ & Oleaster & Oued Touil & Agro-ecosystem & Zaghouan \\
\hline $\mathrm{O} 48$ & Oleaster & Saouaf & Agro-ecosystem & Zaghouan \\
\hline O51 & Oleaster & Mjez El Bab & Agro-ecosystem & Béja \\
\hline O52 & Oleaster & Kélibia & Agro-ecosystem & Nabeul \\
\hline O53 & Oleaster & Kélibia & Agro-ecosystem & Nabeul \\
\hline O55 & Oleaster & Kélibia & Agro-ecosystem & Nabeul \\
\hline O56 & Oleaster & Kélibia & Agro-ecosystem & Nabeul \\
\hline O57 & Oleaster & Kélibia & Agro-ecosystem & Nabeul \\
\hline O59 & Oleaster & Echraf & Agro-ecosystem & Nabeul \\
\hline O61 & Oleaster & Abderrahman & Natural ecosystem & Nabeul \\
\hline O64 & Oleaster & Abderrahman & Natural ecosystem & Nabeul \\
\hline
\end{tabular}

Table 2. Characteristics of microsatellites markers used for the genotyping of cultivated and wild olive trees in the present study.

\begin{tabular}{|c|c|c|c|}
\hline Locus & Repeated motif & Directed sequence $\left(5^{\prime}-3^{\prime}\right)$ & authors \\
\hline ssrOeUA-DCA1 & $(\mathrm{GA})_{22}$ & CCTCTGAAAATCTACACTCACATCC & Sefc et al. [11]; \\
\hline ssrOeUA-DCA5 & $(\mathrm{GA})_{15}$ & AACAAAATCCCATACGAACTGCC & Sefc et al. [11] \\
\hline ssrOeUA-DCA9 & $(\mathrm{GA})_{23}$ & AATCAAAGTCTTCCTTCTCATTTCG & Sefc et al. [11] \\
\hline GapU101 & $(\mathrm{GA})_{8}(\mathrm{G})_{3}(\mathrm{AG})_{3}$ & CATGAAAGGAGGGGGACATA & Carriero et al. [25] \\
\hline Udo012 & $(\mathrm{GT})_{10}$ & TCACCATTCTTAACTTCACACCA & Cipriani et al. [9], \\
\hline Udo017 & $(\mathrm{TG})_{11}$ & TCACCATTCTTAACTTCACACCA & Cipriani et al. [9], \\
\hline Udo024 & $(\mathrm{CA})_{11}(\mathrm{TA})_{2}(\mathrm{CA})_{4}$ & GGATTTATTAAAAGCAAAACATACAAA & Cipriani et al. [9], \\
\hline
\end{tabular}




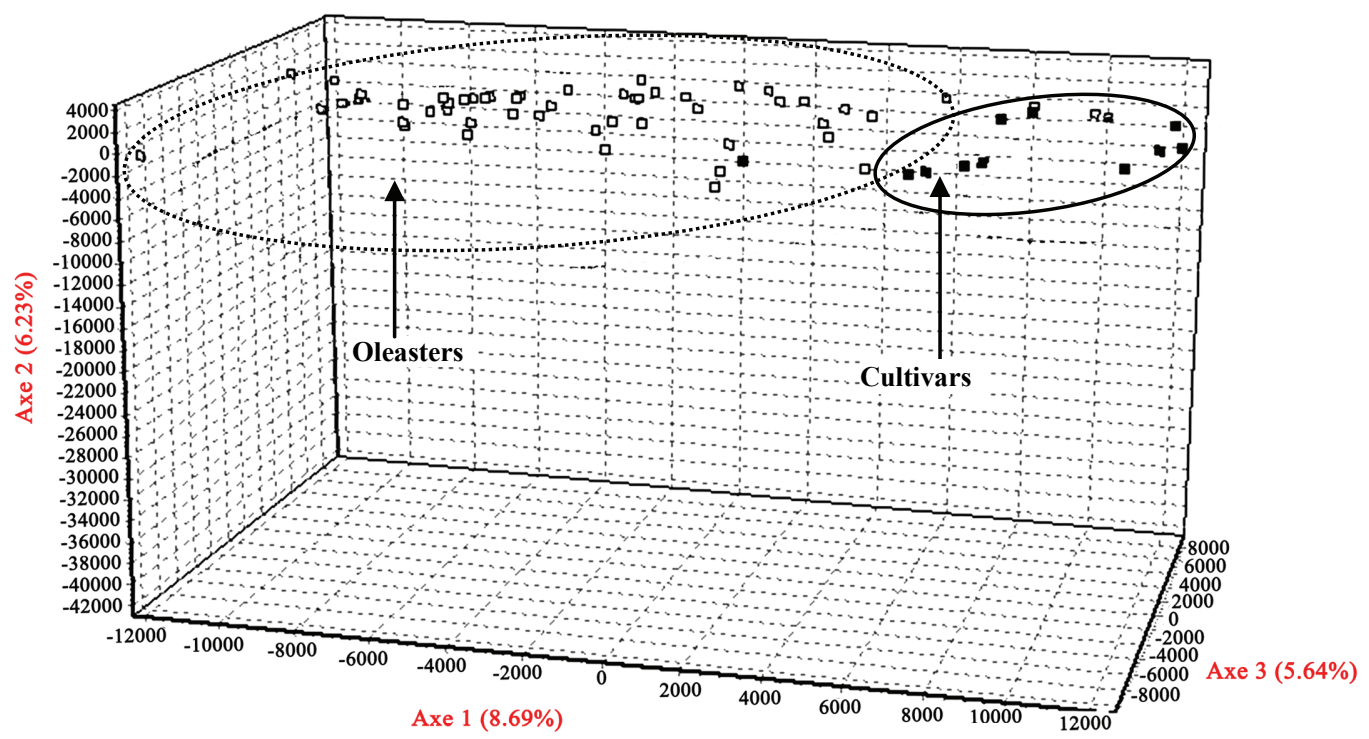

n: olive cultivars; $\square$ : Oleaster olive trees

Figure 1. Factorial correspondence analysis on cultivar and oleaster olive trees based on SSR markers.

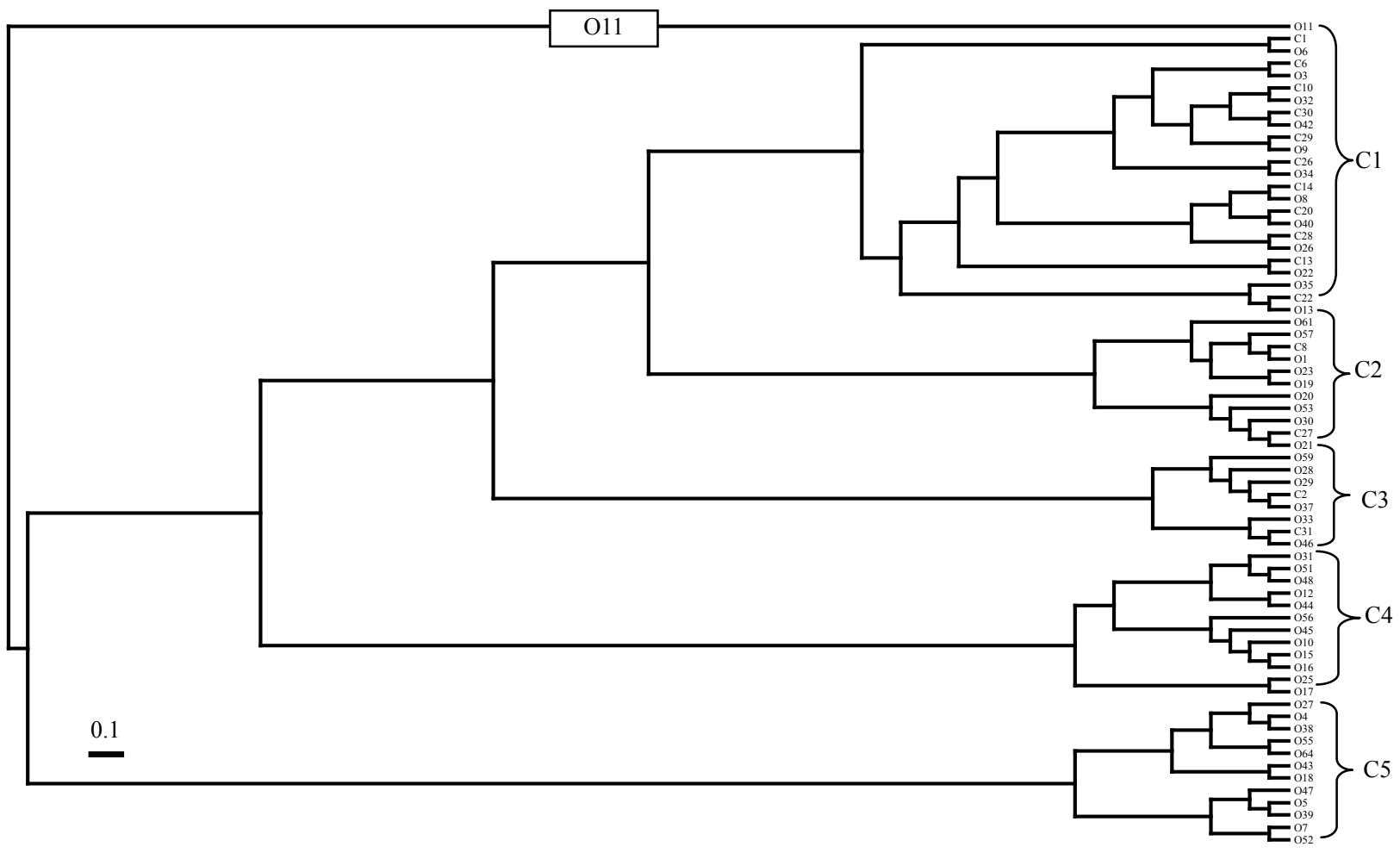

Figure 2. Dendogram based on the SSR data of 15 cultivars and 52 oleasters genotypes generated by UPGMA algorithm. C1 - $\mathrm{C} 5$ indicate five clusters, $\mathrm{O} 11$ is a single oleaster tree; $\mathrm{C}$ : olive cultivar and $\mathrm{O}$ : olive oleaster.

Cluster_3 (CL3) contains two cultivars (C2 Chétoui and $\mathrm{C} 31 \mathrm{Nib}$ ) and six oleaster trees: O29 from natural ecosystem and the others (O59, O28, O37, O33, and O46) from agro-ecosystem. The two cultivars C2 'Chétoui' and C31 'Nib' were close to two oleaster trees from agro-ecosystem $\mathrm{O} 37$ and $\mathrm{O} 46$, respectively.

Cluster_4 (CL4) and cluster_5 (CL5) aggregated only oleaster trees. Cluster_ 4 contains five oleaster trees from 
natural ecosystem $(\mathrm{O} 12, \mathrm{O} 44, \mathrm{O} 10, \mathrm{O} 25$, and $\mathrm{O} 17)$ and seven from agro-ecosystem (O31, O51, O48, O56, O45, O15, and O16). Cluster_5 contains five oleaster trees from natural-ecosystem $(\mathrm{O} 27, \mathrm{O} 38, \mathrm{O} 64, \mathrm{O} 18$, and $\mathrm{O} 7)$ and seven oleaster trees from agro-ecosystem ( $\mathrm{O} 4, \mathrm{O} 55$, O43, O47, O5, O39, and O62). However, the oleaster O11 from natural ecosystem is single and represents a cluster by itself.

These results showed tight relationships between some oleaster trees and cultivars independently of locations and ecosystem.

\subsection{Chloroplast SSR}

In this study, four chlorotypes CE1, CE2, COM and CCK previously determined in olives were found in cultivars and defined the olive origins (Table 3). Oleaster trees from agro-ecosystem and natural sites carry CE1 (6/6), CE2 (0/0), CCK (9/5) and COM (10/7), respecttively, and the lattes do not reveal significant differences for chlorotype frequencies. Whereas, for olive cultivars six carry CE1, six CE2, one COM and six CCK chlorotype.

\section{Discussion}

We used seven nuclear and two cytoplasmic microsatellite markers over 15 cultivars and 52 oleasters that revealed several clusters of cultivars, oleaster trees and several chlorotypes. The morphological means showed a continuous variation between cultivated and wild olive trees [4]. In the present study, molecular markers show also continuous variation, but most cultivars clustered together. This genetic structure probably results from the origin of the cultivars and oleaster trees.

Besnard et al. [18] and Besnard and Bervillé [15] have shown that the CE1, COM, and CCK chlorotypes are prevalent in oleaster trees from the East (CE1) and the West (COM and CCK). In addition, Breton [13] and Breton et al. [14] have shown that CE2 and COM (COM1 and COM2 are variant of COM) originated in Cyprus and Tunisia where they are prevalent in oleaster trees. Consequently, the deep structure in chlorotypes infers that cultivars carrying CE1 or CE2 have ancestors in oleaster or in cultivars from the East. Whereas, cultivars carrying $\mathrm{COM}$ or $\mathrm{CCK}$ have ancestors in oleaster or

Table 3. Chlorotypes of cultivated (cultivars) and wild (oleasters) olive trees based on chloroplast SSR markers. (CE1, CE2: East Mediterranean chlorotype; COM, COM2: West Mediterranean chlorotype; CCK: Maghreb chlorotype; C and O: cultivars and oleasters codes, respectively, used in UPGMA analysis).

\begin{tabular}{|c|c|c|c|}
\hline Chlorotype & Cultivars ${ }^{\text {a }}$ & Oleasters $^{\mathrm{a}}$ & Oleasters $^{\mathrm{b}}$ \\
\hline CE1 & $\begin{array}{c}\text { Sayali (C1) } \\
\text { Chemlali (C8) } \\
\text { Gerboui (C14) } \\
\text { Roumi (C27) } \\
\text { Zarras (C28) } \\
\text { Nib (C31) }\end{array}$ & $\begin{array}{l}\text { O32 } \\
\text { O37 } \\
\text { O45 } \\
\text { O48 } \\
\text { O56 } \\
\text { O57 }\end{array}$ & $\begin{array}{c}\text { O6 } \\
\text { O9 } \\
\text { O18 } \\
\text { O22 } \\
\text { O44 } \\
\text { O64 }\end{array}$ \\
\hline CE2 & Besbessi (C20) & & \\
\hline $\mathrm{COM}$ & Neb jmel (C13) & $\begin{array}{l}\text { O31 } \\
\text { O43 } \\
\text { O59 }\end{array}$ & $\mathrm{O} 7$ \\
\hline COM2 & & $\begin{array}{c}\text { O1 } \\
\text { O3 } \\
\text { O4 } \\
\text { O23 } \\
\text { O34 } \\
\text { O35 } \\
\text { O51 }\end{array}$ & $\begin{array}{l}\text { O8 } \\
\text { O10 } \\
\text { O11 } \\
\text { O12 } \\
\text { O61 } \\
\text { O25 }\end{array}$ \\
\hline $\mathrm{CCK}$ & $\begin{array}{c}\text { Chétoui (C2) } \\
\text { Marsaline (C6) } \\
\text { Meski (C10) } \\
\text { Chaïbi (C22) } \\
\text { Limi (C29) } \\
\text { Rajou (C30) }\end{array}$ & $\begin{array}{c}\mathrm{O} 5 \\
\mathrm{O} 15 \\
\mathrm{O} 16 \\
\mathrm{O} 20 \\
\mathrm{O} 28 \\
\mathrm{O} 40 \\
\mathrm{O} 47 \\
\text { O52 } \\
\text { O53 }\end{array}$ & $\begin{array}{l}\text { O19 } \\
\text { O21 } \\
\text { O26 } \\
\text { O27 } \\
\text { O29 }\end{array}$ \\
\hline
\end{tabular}

a: agro-ecosystem; b: natural ecosystem 
cultivars from the West. Tunisia offers a peculiar situation due to early colonization by Phoenicians, who have probably introduced cultivars from the East into Carthage colony and their further colonies in the West (Spain, Portugal). We can therefore deduce that oleaster trees carrying CE1 are feral trees (progenies of a cultivar by an oleaster or vice versa) either in the agro-ecosystem or natural sites (Table 3). Gene flow appears responsible for the diffusion of the CE1 chlorotypes, but also for the nuclear markers as shown by Breton et al. [14] using Bayesian methods [29].

From these results, we can deduce that 'Sayali' carrying CE1 that clustered with oleaster trees is probably of feral origin. 'Chemlali', carrying also CE1 but aggregated in the FCA intermediate between oleaster trees and cultivars, has probably similar origin. In the Dendrogram 'Chemlali' and 'Roumi' are in the same clusters with some oleaster trees suggesting that 'Roumi' could be a progeny of 'Chemlali' with local oleaster trees. 'Neb Jmel' characterized by the West chlorotype COM was probably selected in the Maghreb region. Oleasters carrying western Mediterranean chlorotypes (CCK, COM) may cluster with cultivars carrying the same chlorotypes in different clusters. Consequently, the chlorotypes are not correlated with the clusters (Figure 2).

Indeed, the UPGMA clustering revealed that each cluster is independent of the chlorotypes which means that kinship relationships by the chlorotypes have been hindered by gene flow between cultivars and local oleaster trees as well as between oleaster trees and cultivars. Obviously, we observed events that have occurred through the female side due to the chlorotypes which is maternally inherited in the olive [21]. The same events are likely existing through pollen flow, but too difficult to detect unless using Bayesian methods. However, in this study, the sampled trees are too limited to study per se gene flow events due to the absence of anchor references for COM and CCK chlorotypes. We suspect that the CCK chlorotype originated from Kabylia [7] where a refuge zone for the olive has been revealed [14], but we do not know whether it has been the only refuge for CCK or if other refuge zones in North Africa or Sicily may have preserved CCK. We also suspected that the COM chlorotypes (COM, COM1, COM2) originate from Tunisia where they are prevalent in natural sites and that correspond to a refuge zone $[13,14]$, but we cannot exclude that, CCK chlorotypes, were kept in refuge zones from Sicily-Corsica. Unfortunately, oleaster trees from central and south Italy have not been genotyped for the chlorotypes [30].

Mixed stands of oleaster trees of natural sites in Tunisia display a huge diversity based on the chlorotypes and nuclear polymorphisms in comparison with other oleaster trees in Mediterranean forests. Oleaster trees transformed into new cultivars should be carefully examined since they are the result into crosses not usually done between genotypes from the East and West of the Mediterranean regions. Seed gene flow is locally detected when in a region where cultivars have been introduced and local oleasters do not carry the same cytoplasm $[12,15]$.

Distinction of a crop from its wild relatives is based on several morphological traits and botanists have usually made distinct species of two taxa [31]. For the cultivated olive trees, it has been traditionally carried out by morphological, agronomic and chemical traits [1,32-35].

Based on the morphology and molecular markers, it is absolutely impossible to determine whether oleaster trees from natural sites are genuine oleasters or not. The phylogeography of the oleaster and cultivars trees is due to permanent and recurrent gene flow. Here, we clearly show that oleaster trees carrying the eastern CE1 chlorotype are present in natural sites of Tunisia. In the frame of the hypothesis that CE1 was absent from refuge zones in the west, it should have been introduced from the East into the West 2500 years ago. In this work, it appeared from the dendrogram (Figure 2) that the oleaster and cu-1 tivar trees clustered by similarities whatever their chlorotypes showing tight genetic relationships. The same results were obtained by Bayesian methods [14].

In Tunisia, many studies have shown the diversity of the Tunisian cultivated olive trees $[22,36]$ but little attention has been given to the Tunisian oleaster trees. Little is known about molecular identification of Tunisian olive.

A close genetic proximity between Tunisian oleasters and cultivars was showed by dendrogram based on nuclear SSR markers (Figure 2). This relationship has already been shown with isozymes [37,38], RAPD and RFLP $[3,7,14]$.

Several molecular studies, including AFLPs, RAPDs, ISSRs, repetitive DNA sequence analysis, chloroplast and mitochondrial DNA polymorphism, have also contributed to elucidate the classification of the Olea complex and the origin of cultivated olive $[2,3,12,15,16$, 39-41].

It has been reported that oil composition for oleaster trees were in agreement with the olive oil norms [4]. Here, we show that those oleasters trees are unique to Tunisia. Crossing the oleasters suggest that breeding the olive and could be done in the country where cultivars may have non-equilibrated oil composition. Indeed, to improve the oil quality it should cutting olive oil with others to satisfy European norms. Screening oleaster trees from the agro-ecosystem and natural sites should lead to new genotypes that could be compared for oil 
composition and yield as it has been done in Australia by Mekuria et al. [42] and Sedgley [43].

These trees are adapted to soil and climate found in Tunisia and therefore they should been screened for their behaviour in the agro-ecosystem to check the yield and quality of the product.

\section{Conclusions}

Cultivars found in Tunisia are of diverse origins based on their chlorotype and nuclear markers. Local genuine oleaster trees are difficult to differentiate from feral trees, and shown to share more or less kinship relationships with autochtonous and introduced cultivars. Those oleaster trees should offer opportunity to screen for new genotypes producing oil with more equilibrated composition than 'Chemlali' as an example and acceptable agronomic behavior to compete with local cultivars to ensure direct selling of the products to the Europe.

\section{REFERENCES}

[1] A. Trigui and M. Msallem, "Oliviers de Tunisie, Catalogue des Varietes Autochtones \& Types Locaux, Identification Varietale \& Caracterisation Morpho-Pomologique des Ressources Genetiques Oleicoles de Tunisie," Vol. 1. (Fr) Ministère de l'Agriculture, IRESA, Institut de l'Olivier, Tunisia, 2002.

[2] A. Angiliollo, M. Mencuccini and L. Baldoni, "Olive Genetic Diversity Assessed Using Amplified Fragment Length Polymorphisms," Theoretical and Applied Genetics, Vol. 98, No. 3-4, 1999, pp. 411-421.

[3] G. Besnard and A. Bervillé, "Multiple Origins for Mediterranean Olive (Olea europaea L. subsp. europaea) Based upon Mitochondrial DNA Polymorphisms," Comptes Rendus Biologie de l'Académie des Sciences, Vol. 323, No. 2, 2000, pp. 173-181.

[4] H. Hannachi, C. Breton, M. Msallem, S. Ben El Hadj, M. El Gazzah and A. Bervillé, "Differences between Native and Introduced Olive Cultivars as Revealed by Morphology of Drupes, Oil Composition and SSR Polymorphisms: A Case Study in Tunisia," Scientia Horticultural, Vol. 116, No. 3, 2008, pp. 280-290.

[5] H. Hannachi, C. Breton, M. Msallem, S. Ben El Hadj, M. El Gazzah and A. Bervillé, "Are Olive Cultivars Distinguishable from Oleaster Trees Based on Morphology of Drupes and Pits, Oil Composition and Microsatellite Polymorphisms?" Acta Botanica Gallica, Vol. 155, No. 4, 2008, pp. 531-545.

[6] A. Fabbri, J. I. Hormaza and V. S. Polito, "Random Amplified Polymorphic DNA Analysis of Olive (Olea europaea L.) Cultivars," The Journal of the American Society for Horticultural Science, Vol. 120, No. 3, 1995, pp. 538-542.

[7] G. Besnard, P. Baradat, D. Chevalier, A. Tagmount and A. Bervillé, "Genetic Differentiation in the Olive Complex (Olea europaea L.) Revealed by RAPDs and RFLPs in the rRNA Genes," Genetic Resources and Crop Evolution, Vol. 48, No. 2, 2001, pp. 165-182.

[8] V. Bronzini de Caraffa, J. Maury, C. Gambotti, C. Breton, A. Bervillé and J. Giannettini, "Mitochondrial DNA Variation from Western an Eastern Mediterranean," Theoretical and Applied Genetics, Vol. 104, No. 6-7, 2002, pp. 1209-1216.

[9] G. Cipriani, M. T. Marrazzo, R. Marconi, A. Cimato and R. Testolin, "Microsatellite Markers Isolated in Olive (Olea europaea L.) are Suitable for Individual FingerPrinting and Reveal Polymorphism within Ancient Cultivars," Theoretical and Applied Genetics, Vol. 104, No. 23, 2002, pp. 223-228.

[10] P. Rallo, G. Dorado and A. Martin, "Development of Simple Sequence Repeats (SSR) in Olive Tree (Olea europaea L.)," Theoretical and Applied Genetics, Vol. 101, No. 5-6, 2000, pp. 984-989.

[11] K. M. Sefc, M. S. Lopes, A. D. Mendoc, M. Rodrigues Dos Santos, M. L. da C. Machado and A. da C. Machado, "Identification of Microsatellites Loci in Olive (Olea europaea) and Their Characterization in Italian and Iberian Trees," Molecular Ecology, Vol. 9, No. 8, 2000, pp. 1171-1173.

[12] C. Breton, G. Besnard and A. Bervillé, "Using Multiple Types of Molecular Markers to Understand Olive Phylogeography," In: M. A. Zeder, D. Decker-Walters, D. Bradley, B. Smith, Eds., Documenting Domestication: New Genetic and Archaeological Paradigms, University of California Press, California, 2005.

[13] C. Breton, 'Reconstruction de l'Histoire De L'Olivier (Olea europaea subsp. europaea) et de son Processus de Domestication en Region Mediterraneenne, Etudies sur des Bases Moleculaires," Ph.D. Biologie des Populations et Ecologie, Paul Cézanne France, 2006.

[14] C. Breton, M. Tersac and A. Bervillé, "SSR Genetic Diversity in Wild Olive (Oleaster, Olea europaea L.) Suggests Several Plio-Pleistocene Refuge Zones in the Mediterranean Basin and Gene Flow with Olive," Journal of Biogeography, Vol. 33, No. 11, 2006, pp. 1916-1928.

[15] G. Besnard and A. Bervillé, "On Chloroplast DNA Variations in the Olive (Olea europaea L.) Complex: Compareson of RFLP and PCR Polymorphisms," Theoretical and Applied Genetics, Vol. 104, No. 8, 2002, pp. 1157 1163.

[16] G. Besnard, B. Khadari, P. Baradat and A. Bervillé, “Olea europaea (Oleaceae) Phylogeography Based on Chloroplast DNA Polymorphism," Theoretical and Applied Genetics, Vol. 104, No. 8, 2002, pp. 1353-1361.

[17] G. Besnard, P. Baradat, C. Breton, B. Khadari and A. Bervillé, "Olive Domestication from Structure of Oleasters and Cultivars Using Nuvlear RAPDs and Mitochondrial RFLPs," Genetics Selection Evolution, Vol. 33, Special Issue, 2001, pp. S251-S268.

[18] G. Besnard, P. Baradat and A. Bervillé, "Genetic Relationship in the Olive (Ole europaea L.) Reflect Multilocal Selection of Cultivars," Theoretical and Applied Genetics, 
Vol. 102, No. 2-3, 2001, pp. 251-258.

[19] C. Sperisen, U. Büchler, F. Gugerli, G. Matyas, T. Geburek and G. G. Vendramin, "Tandem Repeat on Plant Mitochondrial Genomes: Application to the Analysis of Population Differentiation in the Conofer Norway Spruce," Molecular Ecology, Vol. 10, No. 1, 2001, pp. 257-263.

[20] W. Powell, M. Morgante, C. Andre, J. W. McNicol, G. C. Machray, J. J. Doyle, S. V. Tingey and J. A. Rafalski, "hypervariable Chloroplast Microsatellites Provide a General Source of Polymorphic DNA Markers for the Chloroplast Genome," Current Biology, Vol. 5, No. 9, 1995, pp. 1023-1029.

[21] G. Besnard, B. Khadari, P. Villemur and A. Bervillé, “A Cytoplasmic Male Sterility in Olive Cultivars (Olea europaea L.): Phenotypic, Genetic and Molecular Approaches," Theoretical and Applied Genetics, Vol. 100, No. 7, 2000, pp. 1018-1024.

[22] N. Minangoin, "L'olivier en Tunisie," Direction de l'Agriculture et du Commerce Imprimerie Rapide, Nicolas L., 1901.

[23] W. Taamalli, F. Geuna, S. B. Temime, D. Bassi, D. Daoud and M. Zarrouk, "Using Microsatellite Markers to Characterise the Main Tunisian Olive Cultivars 'Chemlali' and 'Chétoui'," Journal of Horticultural Science and Biotechnology, Vol. 82, No. 1, 2007, pp. 25-28.

[24] B. Khadari, C. Breton, N. Moutier, J. P. Roger, G. Besnard and A. Bervillé, "The Use of Molecular Markers for Germplasm Management in a French Olive Collection," Theoretical and Applied Genetics, Vol. 106, No. 3, 2003, pp. 521-529.

[25] F. Carriero, G. Fontanazza, F. Cellini and G. Giorio, "Identification of Simple Sequence Repeats SSRs (GAPU) in Olive Olea europaea L," Theoretical and Applied Genetics, Vol. 104, No. 2-3, 2002, pp. 301-307.

[26] W. S. Oetting, H. K. Lee, D. J. Flanders, G. L. Wiesner, T. A. Sellers and R. A. King, "Linkage Analysis with Multiplexed Short Tandem Repeat Polymorphisms Using Infrared Fluorescence and M13 Tailed Primers," Genomics, Vol. 30, No. 3, 1995, pp. 450-458.

[27] M. Nei, "Genetic Distance between Populations," The American Naturalist, Vol. 106, No. 949, 1972, pp. 283292.

[28] J. Felsenstein, "PHYLIP (Phylogeny Inference Package)," Version 3.5c. Department of Genetics, University of Washington, Seattle, 1993.

[29] C. Breton, C. Pinatel, F. Médail, F. Bonhomme and A. Bervillé, "Comparison between Classical and Bayesian Methods to Investigate the History of Olive Cultivars Using SSR - Polymorphisms," Plant Science, Vol. 175, No. 4, 2008, pp. 524-532.

[30] L. Baldoni, N. Tosti, C. Ricciolini, A. Belaj, S. Arcioni, S, G. Pannelli, M. A. Germana, M. Mulas and A. Porceddu, "Genetic Structure of Wild and Cultivated Olives in the Central Mediterranean Basin," Annals of Botany, Vol. 98, No. 5, 2006, pp. 935-942.
[31] J. Gressel, "Crop Ferality and Volunteerism," Taylor and Francis Boca Raton, 2005.

[32] J. Ruby, "Recherche Morphologique et Biologique sur l'Olivier et sur ses Variétés Cultivées en France," Annales des Sciences Naturelles Botanique, 1918, pp. 1-286.

[33] G. Valdeyron and P. Crossa-Raynaud, "Les Fruits de Tunisie," Annales de Services Botanique et Agronomique de Tunisie, 1950, pp. 23-44.

[34] A. Koutsaftakis, F. Kotsifakis, E. Stefanoudaki and A. Cert, "Etude Triennale sur les Variations de Plusieurs Caractéristiques Chimiques et de Divers Composants Mineurs des Huiles d'olive Vierges Obtenues à Partir d'Olives Cueillies à Différents Degrés de Maturité," Olivae, Vol. 80, 2000, pp. 22-27.

[35] H. Hannachi, M. Msallem, M. El Gazzah and S. Ben Elhadj, "Etude de la Variabilité Pomologique des Olives et de la Composition en Acides Gras des Huiles de 15 Variétés d'Olivier Tunisiens (Olea europaea L.)," Revue des Régions Arides, Vol. 17, No. 1, 2006, pp. 43-64.

[36] H. Camps-Fabrer, "L'Olivier $1^{\text {ère }}$ Partie, L'Olivier et l'Huile dans l'Afrique Romaine," Gouvernement Général de l'Algérie, Direction de l'Intérieur et des Beaux Arts, Service des Antiquités, Imp. Off., Alger, 1953.

[37] R. Lumaret, N. Ouazzani, H. Michaud and P. Villemur, "Cultivated Olive and Oleaster, Two Very Closely Connected Partners of the Same Species (Olea europaea). Evidence from Enzyme Polymorphism," Bocconea, Vol. 7, 1997, pp. 39-42.

[38] R. Lumaret and N. Ouazzani, "Ancient Wild Olives in Mediterranean Forests," Nature, Vol. 413, No. 6857, 2001, p. 700.

[39] M. Amane, N. Ouazzani, R. Lumaret and C. Debain, "Chloroplast-DNA Variation in the Wild and Cultivated Olives (Olea europae L.) of Morocco," Euphytica, Vol. 116, No. 1. 2000, pp. 59-64.

[40] J. Hess, J. W. Kadereit and P. Vargas, "The Colonization History of L. in Macaronesia Based on Internal Transcribed Spacer 1 (ITS-1) Sequences, Randomly Amplified Polymorphic DNAs (RAPD) and Intersimple Sequence Repeats (ISSR)," Molecular Ecology, Vol. 9, No 7, 2000, pp. 857-868.

[41] A. Contento, M. Ceccarelli, M. T. Gelati, F. Maggini, L. Baldoni and P. G. Cionini, "Diversity of Olea Genotypes and the Origin of Cultivated Olives," Theoretical and Applied Genetics, Vol. 104, No. 8, 2002, pp. 1229-1238.

[42] G. T. Mekuria, G. Collins and M. Sedgley, "Genetic Diversity within an Isolated Olive Olea Europaea L Population in Relation to Feral Spread," Scientia Horticulturae, Vol. 94, No. 1, 2002, pp. 91-105.

[43] M. Sedgley, "Wild Olive Selection for Quality Oil Production," A Report for the Rural Industries Research and Development Corporation, RIRDC Publication No 04/ 101, 2004. 